\title{
Introduction: waste
}

\author{
Joshua Gooch
}

As the capitalist mode of production extends, so also does the utilization of the refuse left behind by production and consumption. Under the heading of production we have the waste products of industry and agriculture, under that of consumption we have both the excrement produced by man's natural metabolism and the form in which useful articles survive after use has been made of them. (195)

\section{- Karl Marx, Capital 3}

When we first wrote the call for this special issue of the Iowa Journal of Cultural Studies, the last thing on my mind was Pixar's then-forthcoming film Wall-E (2008). Yet there is perhaps no stronger testament to our culture's aesthetic engagement with waste than the first near-silent thirty minutes of this film as it tries to render ecological apocalypse sublime. By picturing a world of sprawling debris intermittently marked by vertiginous towers of compacted refuse, Wall-E translates Edward Burtynsky's high art trash-scapes into Hollywood aesthetics. Beyond the landscape, though, the eponymous robot is a trope of the film's larger aesthetic strategy. This is not simply because Wall-E acts like a Benjaminian collector by revivifying trash with his treasured scrap collection, but because Wall-E's personified existence as a material excess becomes with his unexpected realization of consciousness something greater. With this turn, art and consciousness become the productive output of an engagement with waste. One must wonder what ideological impasses are at play in the culture at large when A.O. Scott's glowing New York Times review of this "cinematic poem" can 
end by invoking this very problematic: "Or, put another way, some of the same impulses that fill the world of Wall-E - our world - with junk can also fill it with art."

Of course, Wall-E raises the problem of waste in consumer-centered terms, as one might expect of a Hollywood studio production. Although the Earth has been ravaged by Buy'N'Large, a company that seems to combine Best Buy and WalMart in an eerily fascistic intersection of governance and capital, the plot of Wall-E is in essence an argument for consumer responsibility and redemption, not corporate oversight. For this, it is perhaps notable that the film was released before economic crises returned the public gaze from a certain self-absorption to corporate malfeasance. Indeed, given the film's moral tone, it is at once amusing and dispiriting to note that Pixar and its many-tentacled parent, Disney, authorized dozens of disposable action figure tie-ins including Interaction Wall-E, U-Repair Wall-E, and Cube and Stack Wall-E. In the fort-da game of late capitalism, an argument against rampant consumerism aestheticizes waste while simultaneously turning its protagonist into a disposable consumer good, allowing children to signify an impotent solution to what the culture deems an intractable problem.

None of this was on our collective minds when we wrote the call. The ideological imperative to aestheticize waste was certainly in question, but as part of a general question of how at a certain juncture in social production a society finds itself confronted with a large enough quantity of waste that it becomes productive in and of itself. We opened with the above epigraph from Marx since, although written in 1863, Marx's description of an extended and intensified capitalist production in volume three of Capital not only speaks to the waste produced by contemporary economies of scale, but also to the waste produced by consumption as well as its potential reclamation. Marx descriptively illustrates his point with a figure that will recur throughout this special issue-shit. Describing the "colossal wastage in the capitalist economy in proportion to their actual use of it," Marx notes that "in London, for example, they can do nothing better with the excrement produced by $4 \frac{1}{2}$ million people than pollute the Thames with it, at monstrous expense" (195). At once a new raw material for production and a pollutant, waste demarcates production's limits: in developed capitalist production, even shit can signify if it is produced in large enough quantities and there is a will to use it, as modern wastewater plants attest. One might usefully compare Edwin Chadwick's 1842 report on cholera and the pollution of the Thames with Southern California's recent turn toward making wastewater potable, if only to display the extent to which changes in the scale of society and its technical knowledge have changed our relation to waste. ${ }^{1}$

Of course, this begs the question of what qualifies as waste. We could turn to philosophy for an answer. For instance, G.W.F. Hegel made the production of digestive waste a central example in the second volume of his Encyclopedia of the Philosophical Sciences. Taking digestion as the classic example of transubstantiation, Hegel deems the animal production of waste an expression of universality in the face of an opposing world: "Excrement has, therefore, no other 
significance than this, that the organism, recognizing its error, gets rid of its entanglement with outside things" (405). Digestion is a metonymy for Hegelian sublation, and his philosophy revolves around this paradoxical confluence of high and low. In The Phenomenology of Spirit, he illustrates how "the depth which Spirit brings forth from within [...] and the ignorance of this consciousness about what it really is saying, are the same conjunction of the high and low which, in the living being, Nature naively expresses when it combines the organ of its highest fulfillment, the organ of generation, with the organ of urination" (210). Of course, it is perhaps this fascination with such connections that led Nietzsche to write in Ecce Homo: "The German spirit is an indigestion: it does not finish with anything" (694).

All of this, however, is effectively idealist. The late George Carlin's old line "Have you ever noticed that their stuff is shit and your shit is stuff?" seems as concise an idealist definition as any, if a subjective one at that. Our contributors take waste not as an idealist construct but rather an opportunity for material cultural investigation. We asked for essays that examined the functions and constructions of waste in different socio-economic milieus and cultural locations: What is waste and how is it produced, dealt with, and understood? What are the survivals of production and consumption? What becomes of the category of waste in post-Fordist production under the hegemony of immaterial labor? How does the growth of the world market affect the geography of waste?

In our first essay, "From Production to Destruction to Recovery: Freeganism's Redefinition of Food Value and Circulation," Michelle Coyne examines freeganism, an anti-consumer movement that reclaims discarded commodity foodstuffs. Coyne's argument focuses on "dumpster dining as a broad practice [that] offers the opportunity to consider how this human action redefines the space and meaning of waste itself." Freeganism attempts to reclaim the usevalue of commodity foodstuffs, something that the fetishization of exchange in capitalist food production attempts to define via use-by dates and other hygienic constructions. To my ear, an amalgam of anarchist and socialist economic thought on the distribution of use-values suffuses freeganism. ${ }^{2}$ Indeed, freeganism's attempt to rework the notion of productive labor, specifically as labor engaged in the production of capital or conversely as labor engaged in the collection of usevalues for personal consumption, mark freeganism as a kind of autonomy movement similar to Italian autonomia and its attempts to escape the constrictions of factory labor and the labor movement.

We present two essays on waste and art. The first, Maura Coughlin's "Inevitable Grottoes: Modern Painting and Wasted Space," delineates the manner in which the paintings of Vincent van Gogh and Paul Cézanne turned landscape painting away from classical ruins and the picturesque toward the man-made waste spaces of Paris's abandoned rock quarries. Coughlin makes use of land artist Robert Smithson's notion of the wasteland as a kind of nonsite, which she argues is not a postmodern nonspace (or, via Marc Augé, "non-place") but a manner of putting into "dialectical relationships [...] the space of the gallery and places out in the world." Using these nonsites as mediating switch points be- 
tween the reorganization of society and its processes of production, Coughlin argues that a turn from classical genre conventions of landscape painting toward a Baudelarean aesthetics of waste spaces (and their concomitant resonances with representations of feminine sexuality) operates a similar mediation between society and production. Drawing an explicit link between such an aesthetic strategy and the work of Edward Burtynsky, Coughlin argues that these works open a space to contemplate the construction of modern capitalism in an indeterminate space, a trace that inheres within society at both the center and periphery of society.

Our second art essay, Mark B. Feldman's "Inside the Sanitation System: Mierle Ukeles, Urban Ecology and the Social Circulation of Garbage," analyzes the work of Mierle Laderman Ukeles, a performance and process-based artist who has worked closely with the New York Department of Sanitation, as "a radical and ecological vision of interconnectedness." In contrast to the nonsite of waste described by Coughlin, Feldman argues that Ukeles attempts to embed waste in local material processes. Feldman's description of Ukeles seems to me a meditation on social production, one that traces the connection of waste and what Michael Hardt and Antonio Negri have called "immaterial labor," i.e. labor that produces signs, language, codes, affect, and other forms of social connection. Although immaterial labor is often thought of as intellectual labor or cognitive capital, it also contains a specifically affective component that is not only bound up with service work but with feminist struggles over the productivity of domestic labor. Ukeles's work focuses on concepts of interconnection and maintenance, and as Feldman traces its development, moves from such questions about domestic economy and the productivity of feminine labor into questions of service labor and the sanitation system. As Feldman demonstrates, Ukeles uses waste as a metonymy for social production, the material production of society produced in concert by the act of living.

In "'Baby, I am the garbage': James Schuyler's Taste for Waste," Christopher Schmidt offers a reading of James Schuyler's poetry that brings out a simultaneous recuperation and confusion of waste at work in camp aesthetics. From a Marxist perspective, Schmidt's reading discovers in Schuyler a rhetoric of queer social production, with camp operating in his words "at the imaginary switchpoint between bodily waste and cultural waste, between the 'damaged' body (the queer body, the fat body) and the larger social body fed the nutritionless disposables of commodity culture." These attempts to recuperate waste cut across the objective/subjective dichtomy, from the rhetorical subsumption of objects in Schuyler's "Trash Book" to the question and praxes of queerness itself.

Olivia Banner's essay, “"They're literally shit': Masculinity and the Work of Art in an Age of Waste Recycling," takes on the late David Foster Wallace's 2002 novella The Suffering Channel in terms of masculinity, abjection, and mass culture. Banner argues that Wallace launches a critique of the white male as cultural producer via shit, what we might consider an abject materialization of the post-Fordist immaterial laborer's psychic state: "Contemporary media culture $[\ldots]$ has ensured that the male artist/writer not only feels like shit but is also 
expected to produce waste as fodder for the media system. [...] One could say white masculinity is marked for the waste bin, a waste product recycled for mass consumption in a televisual age." Banner's focus on the construction of masculinity in late capital provides an excellent contrast to Christopher Schmidt's essay on James Schuyler, a kind of obverse to the queer attempt to recuperate waste that becomes for the heterosexual men of Wallace's novel a reduction to the abject.

Also included in this volume - though unrelated to our special issue - is an interview of Janice Radway, Walter Dill Scott Professor of Communication and Professor of American Studies and Gender Studies at Northwestern University, by Loren Glass, Associate Professor of English at the University of Iowa. Their wide-ranging conversation moves from thoughts on the influence of Radway's Reading the Romance on cultural studies to the future of literary studies as a discipline. We are quite excited to present this engaging piece here for the first time.

\section{Notes}

${ }^{1}$ For discussion of Chadwick's report, see Mary Poovey, Making A Social Body: British Cultural Formation, 1830-1864 (Chicago: University of Chicago Press, 1995) 115-131. For information on Southern California's attempts to make wastewater potable, see Angela Lau, "Wastewater to Tap Water," San Diego Union-Tribune 23 January 2009, 14 March $2009<\mathrm{http}: / /$ www3.signonsandiego.com/stories/2009/jan/23/1 m23reclaim23151-wastewatertap-water>; Mike Lee, "Divisive Water Proposal Advances: Council to Discuss Treating Wastewater," San Diego Union-Tribune 27 July 2006, 14 March 2009 $<$ http://www.signonsandiego.com/uniontrib/20060727/news_7m27reuse.html>; Mike Lee, “'Repurified' Wastewater Backed for Home Use: Citizens Panel Forwards Proposal to S.D. Council," San Diego Union-Tribune 15 July 2005, 14 March $2009<$ http://www.signonsandiego.com/uniontrib/20050715/ news_ln 15 tap.html>.

${ }^{2}$ For instance, Rudolf Hilferding lays out the classic socialist position of the rational distribution of use-values against the irrational distribution of use-value via exchange-value. Freeganism's decentralization, however, places it amongst anarchist thinkers like Bakunin and Kropotkin, and indeed the website that forms part of Coyne's argument (http://freegan.info) now includes an e-text of Proudhon's early anarchist What is Property? (1840). See Rudolf Hilferding, Finance Capital, trans. Tom Bottomore (London: Routledge, 1980).

\section{Works Cited}

Augé, Marc. Non-Places: Introduction to an Anthropology of Supermodernity. London: Verso, 1995.

Hegel, G.W.F. Philosophy of Nature. 1830. Trans. A.V. Miller. Oxford: Clarendon Press, 2004. Vol. 2 of The Encyclopedia of the Philosophical Sciences. 3 Vols.

---. Phenomenology of Spirit. 1807. Trans. A.V. Miller. Oxford: Oxford UP, 1977. Marx, Karl. Capital. Vol. 3. 1894. Trans. David Fernbach. London: Penguin Books, 1981.

Nietzsche, Friedrich. Ecce Homo. 1888. Rpt. in Basic Writings of Nietzsche. 
Trans. Walter Kauffman. New York: Modern Library, 1992. 657-791.

Scott, A.O. "In a world left silent, one heart beeps." New York Times 27 June 2008. 14 March $2009<$ http://movies.nytimes.com/2008/06/27/movies/ 27wall.html>.

Wall-E. Dir. Brad Bird. Pixar, 2008. 